\title{
Cultural patterns of corrupt decision-making in Russian organizations
}

\author{
A. Fürstenberg \\ Heidelberg University, \\ 1, Grabengasse, Heidelberg, 69117, Germany
}

For citation: Fürstenberg A. Cultural patterns of corrupt decision-making in Russian organizations. Vestnik of Saint Petersburg University. Sociology, 2020, vol. 13, issue 4, pp. 393-406.

https://doi.org/10.21638/spbu12.2020.403

The persistence of corruption in Russia is seen in path-dependent political structures on the one hand, while, on the other hand, concrete corruption-promoting mechanisms can be theoretically described at the level of the actor. The former approach lacks a general explanation of corruption, while the latter lacks the immanent possibility of embedding corrupt practices in specific cultural patterns. Recent approaches in organizational research promise a fruitful connection of both via the idea of organizational corruption, which explains corruption as a normalization process in an organizational context. The present article aims at extending this approach by an analytical model of decision-making in organizations based on a neo-institutional framework. Decision-making situations will be constructed in the activity structure of organizations as the tension between formal-legal requirements and the legitimate goals of the organization as set out in the formal structure. Depending on whether decisions are oriented in accordance or or against legal requirements and the legitimate goals of the organization, a compliant decision, individual corruption, organizational corruption or whistle blowing becomes more likely. Thus, the link between different cultural concepts in Russia and corruption are systematically highlighted and integrated into the present model. It is shown that culturalhistorical patterns cannot be generalized to Russia, but often only promote corruption when specifically embedded in organizations.

Keywords: organizational corruption, neo-institutional approach, analytical framework, corrupt decisions, cultural patterns.

\section{Introduction}

There is a broad scientific consensus on the negative social effects caused by corrupt practices in politics and business. The consequences include worldwide financial damage amounting to trillions of dollars [1;2], loss of confidence in political actors and institutions [3], undermining of health care systems [4; 5] and massive environmental damage [6]. Russia appears to be a prime example of the persistence of corrupt practices and, despite all efforts to combat corruption [7;8], has occupied a low position in the CorruptionPerception-Index for decades [9].

Beside the causes of corrupt decisions by actors at the micro level, which have been well studied, especially in international, economic experimental research [10], the ethnographic research literature describes historical path-dependent structures in Russia that

(c) Санкт-Петербургский государственный университет, 2020 
perpetuate corruption [11]. The former approach has problems with embedding cultural patterns in its rational-choice theoretical orientation [12] and thus incorporate specific Russian characteristics into the explanatory model. The latter lacks an analytical focus on explaining concrete decision-making processes that lead to corruption. At the heart of both approaches is the idea that corruption arises when individual actors seek personal enrichment - be it for monetary gain or the concentration of political power. Subsequently, the question arises as to how both explanatory directions can be brought together without losing the claim to explain corruption in general or having to theoretically fade out path-dependent cultural specifics?

Building on an organizational-sociological perspective on corrupt practices, the article describes a connection between decision-making at the micro level and the cultural imprint of decision-making processes at the macro level. This is because a large number of corrupt decisions emerge and establish themselves only in the context of organizations or are aligned with organizational criteria and do not necessarily aim at personal profit prospects [13-15]. The conceptual embedding of corrupt practices in an organizational context then allows a systematic perspective on the linkage of both levels of analysis to uncover mutual factors influencing the emergence of corrupt decisions.

To do so, the aim of this article is to develop an analytical framework that can claim generality of corrupt practices and also enable the systematic integration of case-specific explanatory factors. First, the current theoretical concepts for explaining corruption at the micro-, meso- and macro-levels will be summarized. Secondly, the theoretical connection of the levels in an neo-institutional theoretical concept is presented, from which the analytical framework of decision-making situations in the activity structure of organizations is derived. Third, the cultural context of corrupt practices in Russia will be spelled out and differentiated on the dimensions of the analytical concept. The article ends with a short conclusion and discussion of the theoretical conception.

\section{The state of the art}

Multidisciplinary corruption research is conducted in criminology, economics, political science, sociology and other fields. Beside differentiations into types of corruption, such as enrichment in office vs. bribery, legislative vs. executive corruption, nepotism and patronage, etc. $[16 ; 17]$, we distinguish three main focuses in the theoretical literature on corruption: Firstly, actor-centred approaches focus on the modelling of alternative courses of action in which corrupt decisions are made on the basis of either rational calculations or the normative orientations of actors. Secondly, the affinity for corruption in a country or society is understood as a path-dependent, cultural pattern. Thirdly, explanations that refer to the procedural implementation of corrupt practices in organizational structures.

Actor-centred theories referring to rational choice theoretical assumptions construct decisions of actors along the possible realisation of their own preferences in consideration of the personal benefits and costs involved. A decision for an action is made if the personal (expected) benefit of the action is higher than the (expected) costs of the option and if the (expected) overall benefit of the action is greater than that of all other alternatives [18]. Rational-choice theories of crime suggest that corruption occurs when the personal (monetary) benefit is estimated to be greater than the resulting penalties and their anticipated probability of detection [19]. 
In contrast to the assumptions of a rational cost-benefit analysis, approaches of norm-oriented actions focus on the reduction of complexity for decisions of actors by established or missing norms and values. Accordingly, options for goals and actions are over-complex and are limited and therefore manageable by internalized norms and values. While the establishment of different norms and values is theoretically regarded as being anchored in social structures, they only develop their function as a guideline for decisions for a particular actor $[20 ; 21]$. Sub-cultural theories then describe the distinction between specific group norms and dominant social norms, which can sometimes conflict. If socially accepted goals are difficult to achieve by parts of the population, action-oriented norms can establish themselves in subcultures that also legitimize illegal means. Corruption occurs when it is normatively accepted within the group or sub-culture [22].

Anomy theoretical approaches develop the assumption that the introduction of economic requirements into other spheres of life devalues their original functions. Economic rationalities come to the fore, while other social norms of action control become less important. As a result of a rational calculation for one's own enrichment and a simultaneous subjective loss of significance of the resulting damage for third parties, corrupt actions then arise [23-25].

The voluntarist theory of crime refers to developed values that differentiate the goals of actors and thus select alternatives for actions in a complex environment. Accordingly, the moral development of the subject affects the acceptance of (legal) norms and the legitimacy of certain goals. Traditional value orientations then lead to greater norm acceptance, while materialistic value orientations tend to favour norm deviations and lead to delinquency [26].

In contrast to actor-centred theories, path-dependent culture-theoretical approaches understand corruption as a historically established process at the macro level, which then diffuses into individual areas of social life and ensures a higher affinity for corruption. Thus, Levin and Satarov (2000) [27] concretize path dependencies from the transition period of the Soviet Union to post-Soviet Russia for the persistence of social norms, which lead to "[a] dministrative bodies in Russia, especially at the regional level, continued to play on the economic field according to rules that they established for themselves" [27, p. 117].

While Avtonomov (2006) [28] more generally describes the historical connection between state, society and economy in Russia as conducive to corruption [28], Cheloukhine and King (2007) [29] specify the causes of the high degree of diffusion of corruption in a steady system of social relations between organized crime, law enforcement and civil service [29].

Ledeneva (2013) [30] points to the problem of virulent corruption and Russia's authoritarian political system with a dilemma situation according to which authoritarian political control limits the differentiation of institutional control mechanisms and the lack of control mechanisms in turn makes authoritarian control necessary to keep the state capable of action. This sistema then leads to "that currently Russia cannot rely on the institutions of civil society or any institutionalized system of checks and balances" [30, p. 1138] and is stabilized by network structures between an Inner Circle of the political party, Core Contacts in the national ministries, Mediated Contacts in the regional administrations and Useful Friends in the economic sphere [30].

While the aforementioned approaches on the actor level lacks the concrete selection of established values and norms to the respective decisions on action, path-dependent 
attempts cover only a specific spectrum of the origins of corrupt practices and missing out a generally valid explanation for their emergence.

Between actor-centred theories and path-dependent explanations there are organizational sociological approaches. These construct corrupt decisions in organizational situations, in which the choice of corruption depends not only on structural conditions but also on the normative and organizational-cultural characteristics of the organization. Thus, Anand, Ashforth and Mahendra (2004) [31] describe the persistence of corrupt practices in organizations as a mutually reinforcing process of rationalization strategies of existing corruption and the selection of these strategies via the socialization of new employees in the respective company. Corrupt practices consequently diffuse into the normative order of the organization as business as usual and are continued without question $[31 ; 32]$.

Aguilera and Vadera (2008) [33] specify the interplay between the basis of authority, the underlying motives and the evaluation strategies of the decisions made by actors at the top of the company hierarchy as an explanatory mechanism for the establishment of organizational forms of corruption. Corruption thus does not simply remain rooted at the individual level of actor decisions, but can only be adequately described in various forms through organizational-cultural factors such as the attribution of authority and the available evaluation strategies [33].

Campbell and Göritz (2014) [34] complement an organizational culture perspective and distinguish between corrupt and non-corrupt organizations, each of which is supported by independent norms and values at the managerial and employee level [34].

What remains inadequately explained, however, is how the relationships between the cultural embedding of corruption, its organizational embedding and the decisions of actors coincide [35; 36]. Pohlmann, Höly and Klinkhammer (2016) [15] make a central contribution, in which they describe corruption in the context of organizations on the basis of an institutional theory approach $[15 ; 37]$. Conceptually, they distinguish between individual corruption, which is primarily located on the recipient side for personal profit prospects, and organizational corruption, which is oriented towards organizational and institutional criteria $[15 ; 38 ; 39]$. The chance of organizational corruption becoming established is therefore based firstly on its usefulness for the organizational goal, secondly on its legitimacy through unwritten rules in the organization and the organizational field, thirdly on the integration of organizational deviance into the organization-specific reward system and fourthly on the hierarchical level of deviant personnel [15]. In the context of an empirical study of organizational deviance in the form of manipulation in transplantation centres in Germany, Pohlmann and Höly (2017) [40] reconstruct the above criteria using general mechanisms of competitive pressure, hierarchical pressure, rationalization and legitimization and socialization [40]. While the separation of individual and organizational corruption as distinct phenomena explained by different theoretical approaches seems problematic, their approach includes institutional criteria in the organizational environment, as well as organizational structural and cultural factors.

\section{The analytical framework of corrupt decisions in organizations}

Based on the neo-institutional theory, the explanatory approach of corrupt practices in the organizational context by Pohlmann, Höly and Klinkhammer (2016) [15] will be expanded with a narrower analytical concept of decision-making situations in organiza- 
tions. This concept should firstly retain the theoretical scope of the explanation of corrupt practices, secondly re-arrange the theoretical preconditions on concrete levels of analysis, and thirdly integrate into a model not only organizational corruption but also corruption based on personal profit prospects.

As objectifications of reality, institutions are concretized in a mutual legitimation process between actors and their environment. They structure the scope of action through more or less shared understandings of the reality [41]. For their decisions, actors then experience validity through institutions as "a compelling massivity for the objective reality to be internalized" [41, p. 184; 42; 43]. Institutions are the central explanatory factor for the spread of organizational structures and constitute the environment on which organizations orient themselves [42; 44]. If organizations can plausibly demonstrate that they adapt legitimate expectations, they are more likely to acquire resources from this environment [42;45].

From a theoretical perspective the organizational environment can be divided into an organizational and an institutional field. As an organizational field, DiMaggio and Powell address "these organizations that, in the aggregate, constitute a recognized area of institutional life: key suppliers, resource and product consumers, regulatory agencies, and other organizations that produce similar services or products" [44, p. 148; 46]. The institutional field in which the organization is embedded is constructed as an emergent set of binding laws, normative expectations of best practice in organizational design and unquestioned expectations of organizational structures. Regulatory institutions are laws, contracts and the like which exert a pressure to act by threatening to impose sanctions. Normative institutions restrict actions via the moral pressure of internalized values and the pressure of expectations of generalized norms in the environment. As soon as views on reality come into play without being questioned, they are typified as cognitive institutions [47]. What appears to be rational and legitimate in the institutional field binds organizations to the extent that "organizations are driven to incorporate the practices and procedures defined by prevailing rationalized concepts of organizational work and institutionalized in society" [42, p.340].

Regulatory institutions in the form of laws are used as an analytical reference point for the present concept of corruption. They serve as a basis for assessing whether a disposition to act can be described as corrupt or not. In the demarcation to regulative institutions, the structure of cognitive and normative institutions is hereinafter summarized as the cultural environment. Legitimate goals of the organization are directed at this cultural environment.

If cultural and legal institutions conflicts with each other, this may lead to a decoupling between the formal façade of the organization and the actual activity structure within the organization [42]. Thus, on the one hand the formal structure serve as a façade to remain connecTable in the organizational environment and on the other hand in the "inner-life" of the organization unclear decision-making situations for the staff arise. Decision-making situations in organizations are therefore (possible) tension ratios between the alignment with the legitimate goals of the organization and the orientation towards regulatory institutions in the organizational environment. So they can be in the sense of the legitimate goals and/or the regulative guidelines or contradict these (Table 1).

If a decision is aligned with both legal rules on corruption and the legitimate objectives of an organization, the decision is called compliant ${ }^{1}$. Decisions that are made against

${ }^{1}$ The distinction between the basis of the decision and the factual action remains central. The latter can be regarded as corrupt in the form of unintended consequences or in the assessment by third parties. However, this assessment remains outside the present analytical concept. 
the legitimate goals of an organization, but are aligned with the regulatory environment of the organization are denominated here as whistle blowing. In contrast to a conceptual narrowing of whistle blowing, it is pointed out that in the organizational decision-making process it is more likely to accept damage to one's own organization than to make illegal decisions. Consequently, the probability of disclosing insider information in favour of legal compliance increases. When decisions are directed against regulatory institutions, we speak of corruption. If the decisions are in line with organizational goals, organizational corruption is more likely. In cases of personal enrichment and in contradiction to organizational goals, the probability of individual corruption increases.

Table 1. Decision types of the staff depending on the alignment with legitimate objectives of the organization and the regulatory organizational environment

\begin{tabular}{|l|l|l|}
\hline \multicolumn{1}{|c|}{ Orientation of the decision } & \multicolumn{1}{|c|}{$\begin{array}{c}\text { Along the legitimate goals } \\
\text { of the organization }\end{array}$} & $\begin{array}{c}\text { Contrary to the legitimate goals } \\
\text { of the organization }\end{array}$ \\
\hline $\begin{array}{l}\text { Along the regulatory organiza- } \\
\text { tional environment }\end{array}$ & Compliant Decision (C) & Whistle Blowing (WB) \\
\hline $\begin{array}{l}\text { Contrary to the regulatory orga- } \\
\text { nizational environment }\end{array}$ & Organizational Corruption (OC) & Individual Corruption (IC) \\
\hline
\end{tabular}

S o u r c e: Own representation.

In everyday decision-making situations organizational-cultural rules intervene, which help to structure the decisions of the staff $[15 ; 31 ; 34]$. For if all possible decisionmaking options had to be formally determined and thought through, the functionality of an organization would fail due to the over-complexity of its own rule-making [13]. Actors are socialized in a cultural framework and, through their work as personnel, they bring culturally learned rules into the organization, which - embedded in the organizational culture - can develop validity there for concrete dispositions to act. Culturally socialized knowledge increases the chance that personnel will orient themselves to it in decisionmaking situations. For the integration of institutional expectations in an organizational context makes their transfer, maintenance and persistence more likely [48]. Therefore, if actors are socialized in an environment in which deviations from formal rules are normatively more accepted the chance of deviating from regulatory institutions increases inside the organization. The individual actor is then confronted not only with the formal requirements of the organization (cultural institutions), the legal regulations (regulative institutions), but also the shared, informal expectations within the organization (organizational culture) and his or her own socialization (cultural setting).

\section{Cultural concepts of corruption in Russia}

As a general model for describing corrupt practices, the analytical framework relies on further short-range models from which hypotheses for specific factors influencing the decision-making process can be derived. In order to develop corruption research in Russia in a fruitful way, it is necessary to examine the cultural preconditions, which find their way into the formal structures of organizations as institutionalized expectations and can be taken into account in corrupt decision-making [49]. They will be differentiated 
between wider institutionalized expectations on legal behavior and institutions related more specifically to organizational work ${ }^{2}$.

Suhara (2004) [50] refers to the scepticism about the prevailing legal system that is anchored in the Russian culture. With the term Legal Nihilism, he describes a general mistrust of the law in general, the law enforcement authorities and a lack of mental internalization of the law in the population. He contrasts Russian Legal Nihilism with the culture of the rule of law anchored in Western Europe and attributes the difference to a path-dependent development since tsarist Russia. The starting points for this development are identified as the low degree of formal codification of the law of the time and the arbitrary interpretation within the former judicial system, which continue to have an effect throughout the Soviet era and into the present day. Parallel to a lower level of cultural anchoring of the formalized legal system, he points to the historical co-development of an Ethical Dualism. This describes the peculiar mentality according to which moral over legal premises are set in everyday decisions [50]. Using the description of the term Potemkin Villages Ledeneva (2013) [30] explains the phenomenon of the separation of legality (zakonnost) and justice (spravedlivost) in Russia: "The duality of norms, the gap between the formal and informal, and the arbitrary nature of their application make the practical norms indispensable know-how" [30, p. 1143]. The term Potemkin Villages comes from stories of a fake porTable village built solely to impress Empress Catherine II by Grigory Potemkin and stands for the distinction between a façade and the reality behind. Together, the historical developments in Russia point to a loss of importance of regulatory institutions in the form of laws and thus, according to the present model, increase the chances for both individual and organizational corrupt decisions.

Next to the cultural relationship to regulatory institutions, other concepts emerged in Russia that have been consolidated as normative institutions and can be related to corrupt decisions. Feeding (kormlenie) is described as "a system in which the people of each district 'fed' the ruler's representatives on food and other material supplies, namely korm (stipend in kind)" [50, p. 389]. Originally established in the late Medieval Times, it was regarded on the one hand as a temporary reward for civil servants who could thus fill their own pockets and on the other hand as an incentive to fulfil various regulatory functions in the constituencies despite the low level of central control. Feeding developed after its official prohibition in 1555 into an informal norm of abuse of office up to a "personalized system of allocation, the culture of privileges, and the redistribution principles have promulgated free-riding, which became most pronounced in Putin's Russia in the form of kickbacks" [30, p. 1141]. As an informal form of exchange, Feeding is both deviant from the law per se and indifferent to the legitimate goals of an organization. In principle, it aims at personal profit prospects and seems to increase the chance for decisions in favour of individual corruption along the aforementioned type formation.

The Blat phenomenon, which originates from the times of the Soviet Union, stands for the informal exchange of favours in personal networks under restrictive access to goods and services. In contrast to Kormlenie, Blat is not necessarily an abuse of authority and, as opposed to bribery, it rules out direct barter transactions [51; 52]. Blat, as a culturally rooted social practice, establishes itself as a network of personal favours in opposi-

${ }^{2}$ Conceptually, specific explanatory factors are not evaluated deterministically. They express the chances of realizing individual types of decisions within an organization. In this form, they serve to form hypotheses, whose expression in probabilities remains an empirical question. 
tion to regulatory institutions and the legitimate aims of organizations for the benefit of personal advantages ${ }^{3}$. As a socialized, normative institution, it seems to favour individual corruption over the other three types of decisions.

Another established normative rule is found in the term krugovaya poruka, originally a kind of joint responsibility for the members of a village community. Used as a traditional means of government, the entire community was held responsible if a governmental requirement (e. g. taxes or other levies) was not met. As a result, communities responded with a closed system of informal checks and balances among themselves with consequent restrictions on individual rights for the benefit of the collective [30]. Krugovaya poruka changed after its formal abolition into a form of internal group cover-up of crimes against outsiders. It protects group interests through norms of mutual control against both the external regulatory environment and whistleblower from within the group. This leads to the expectation that the probability for whistle blowing will be reduced as a decision type in favour of organizational corruption.

Concepts in Russia which may influence decision-making opportunities of actors via the mechanism of socialization as normative institutions are supplemented by specific deviant practices of organizations. Thus, especially in companies, these seem to have established themselves as a legitimate response to longer-term allocation problems inherent in the Soviet system, path-dependent in the formal structures of organizations [53]. One form of deviant practices widespread in Russian companies was the recruitment of middlemen, also known as Tolkachi. These were paid to acquire non-legally available resources to achieve the companies' planning goals. Tolkachi made use of personal relationships with other companies and authorities [52; 54; 55]. In contrast to production networks, in which resources were mutually exchanged as required, Tolkachi were mainly paid in roubles or hard currency [56]. Ledeneva (2001) [52] refers to a historical development of the Tolkachi, whose current function is still the circumvention of existing rules for the benefit of the organization, but this function is fulfilled either by their own departments or private security services (Krysha) [52]. This integration of normative practices into the formal structure of enterprises indicates an orientation towards the legitimate goals of the organization contrary to the regulatory institutions in its environment. Therefore it can be assumed that there is an increased chance for organizational corruption in decisionmaking situations.

Otkat refers to the informal practice widespread in Russia, which, unlike the use of Tolkachi, takes the form of kickback payments or commissions from companies to state officials or other companies in order to secure advantages for one's own company [57]. According to Avtonomov (2006) [28], Otkat is closely linked to the transition from a planned to a market economy and the associated dynamization of state influence on the economy. Compared with the previously centrally determined distribution of resources, access to these resources has become increasingly decentralized and regulated via partially privatized companies [28]. With dwindling control possibilities, this paved the way for the distributing agents to introduce kickback payments informally, so that Otkat "have become the core modus operandi of the informal exchange of favours" [57, p. 278]. While this informal norm argues for a dilution of the impact of regulatory institutions, a distinction

${ }^{3}$ If, on the other hand, the network as a social form is placed in the focus of the analysis, Blat would conform to the goals of the overall network and would have to be reinterpreted analytically along the network criteria as a special form of organizational deviation. 
must be made between the donor and the recipient side in the alignment with the legitimate goals of the organisation. While the paying side is oriented towards the legitimate objectives of the company, an environment shaped by Otkat promotes organizational corruption. In the kickback recipient's perspective however, personal gains are at odds with legitimate organizational goals and individual corruption becomes more likely.

From earlier, structural factors various concepts promoting deviation developed in Russia, which established themselves as normative and cognitive institutions [58]. These may find their way into daily decision-making situations in different ways: "Reliance on unwritten rules is an outcome of the inefficiency of formal rules and the mechanisms for enforcing them, on one hand; and people's lack of respect for formal rules and their explosive attitude towards formal institutions on the other" [52, p. 13]. In summary, for individual culturally established concepts it is possible to find links to the preceding analytical model of organizational decision-making situations and to derive expected opportunities to influence these decisions (Table 2):

Table 2. Cultural concepts in Russia and their expected influence on decision-making situations

\begin{tabular}{|c|c|c|}
\hline Cultural concept & $\begin{array}{l}\text { Integration in the analytical concept } \\
\text { of decision situations }\end{array}$ & $\begin{array}{l}\text { Expected influence on } \\
\text { decision-making } \\
\text { situations }\end{array}$ \\
\hline Legal Nihilism & $\begin{array}{l}\text { Cultural loss of importance of regulatory insti- } \\
\text { tutions }\end{array}$ & OC $(\uparrow)$, IC $(\uparrow)$ \\
\hline $\begin{array}{c}\text { Ethic Dualism/ Potemkin } \\
\text { Villages }\end{array}$ & $\begin{array}{l}\text { Cultural loss of importance of regulatory insti- } \\
\text { tutions }\end{array}$ & OC $(\uparrow)$, IC $(\uparrow)$ \\
\hline Feeding (Kormlenie) & $\begin{array}{l}\text { Adaptation of the normative institution via the } \\
\text { staff in the activity structure/ organizational } \\
\text { culture }\end{array}$ & IC $(\uparrow)$ \\
\hline Blat & $\begin{array}{l}\text { Adaptation of the normative institution via the } \\
\text { staff in the activity structure/ organizational } \\
\text { culture }\end{array}$ & $\mathrm{IC}(\uparrow)$ \\
\hline $\begin{array}{l}\text { Joint Responsibility } \\
\text { (krugovaya poruka) }\end{array}$ & $\begin{array}{l}\text { Adaptation of the normative institution via the } \\
\text { staff in the activity structure/ organizational } \\
\text { culture }\end{array}$ & OC $(\uparrow), \mathrm{WB}(\downarrow)$ \\
\hline Tolkachi & $\begin{array}{l}\text { Adaptation of the normative institution in the } \\
\text { formal structure }\end{array}$ & OC $(\uparrow)$ \\
\hline Otkat & $\begin{array}{l}\text { Adaptation of the normative institution in the } \\
\text { formal structure }\end{array}$ & $\begin{array}{l}\text { Briber: OC }(\uparrow) \\
\text { Bribee: } \operatorname{IC~}(\uparrow)\end{array}$ \\
\hline
\end{tabular}

Note: OC - Organizational Corruption, IC - Individual Corruption, WB - Whistle Blowing, $\uparrow$ - supporting mechanism, $\downarrow$ - inhibiting mechanism.

S o u r c e: Own representation

The integration of the presented Russian cultural concepts into the present analyti$\mathrm{cal}$ framework takes place on three levels. First, at the level of regulatory institutions, whose general loss of legitimacy in Russia seems to be deeply rooted in Russian society 
and thus influences decision-making situations in organizations. Secondly, through socialized normative institutions, which enter the activity structure of organizations through their staff and thus influence decision-making processes. Thirdly, through normative institutions, which are integrated into the formal structure of organizations through their legitimate recognition in an isomorphic process. The chance of making corrupt decisions cannot therefore be generalized to Russia at all, but depends on the pervasion of the concepts in the organizational context. Depending on the degree of diffusion of the cultural concepts, there are tendencies for decision-making processes in organizations in Russia, which increase the chances for the organizational and/or individual corrupt type of decision and, in the case of krugovaya poruka, additionally reduce the chance of whistle blowing.

\section{Conclusions and discussion}

A major part of previous research on corrupt practices focuses their description and explanation on specific levels of analysis. These approaches produce helpful insights into concrete mechanisms that promote and/or inhibit corruption, but the degree of specialization obstructing the view on interactions between the micro-, meso- and macro-level. Based on the explanation of organizational corruption by Pohlmann, Höly, Klinkhammer (2016) [15], this article develops an analytical concept to link legal, cultural and organizational-cultural mechanisms. Corrupt practices can thus be systematically investigated as decision-making processes in organizations and brought together into a holistic picture of the description of corruption. The model expands the generality of the explanation to include organizational and individual corruption, compliant decisions and whistle blowing. It allows for the integration and development of concrete hypotheses at different levels of analysis, also. The construction of corruption as a decision-making process in organizational situations remains open to the findings of research on micro-connections, organizational factors of influence at the meso-level, as well as the results of ethnographic, path-dependent mechanisms at the macro level.

This was examined using culturally established concepts in Russia in order to advance the basis of hypothesis for the empirical proof of the variance of corruption in Russian organizations. The cultural paths are directed at different perspectives in the analytical model of corrupt decision making. In addition to general tendencies of a loss of significance of regulatory institutions, specific concepts only unfolds their influence on corrupt types of decisions when embedded in concrete organizations.

A strength of neo-institutional approaches is the comprehensive consideration of the organizational embedding of social contexts and the ability to describe them in terms of general theory. This level of abstraction limits the general validity of empirical results because of the implicit assumption of emergence and theory-immanent interactions between all possible variables. Therefore, the modeling of the activity structure as a decision-making situation can serve as an analytical bridge to empirically tesTable hypotheses without having to throw the conceptual strengths of the theory overboard. Despite the aforementioned cultural mechanisms are anchored in Russian history, their degree of institutionalization and persistence remains empirically open. The concrete influence on the decision-making process in organisations thus always depends on the concrete institutional and organisational field. 
For further research, the presented model offers several possibilities for empirically testing theory-immanent relationships: Firstly, concrete institutional influences on internal organizational decisions can be tested using the aforementioned decision types; secondly, conflicts of institutional expectations and the resulting effects can be mapped; thirdly, the analytical approach allows comparisons within and between organizations, types of organizations, organizational and institutional fields at different levels of abstraction; fourthly, existing findings can be integrated into one model. In particular, the model provides a simple blueprint for empirical access to various forms of deviations in an organizational framework, which goes beyond the confinement of other theoretical models.

\section{References}

1. Auzan A., Kruchkova P. Administrative barriers in economics: Issues of deregulation. Voprosy Economiki, 2001, vol. 5, pp. 73-88. (In Russian)

2. Gaspar V., Hagan S. Corruption: Costs and Mititgating Strategies. IMF Staff Discussion Note, 2016.

3. Leys C. What is the Problem about Corruption? Heidenheimer A., Johnston M. (eds) Political Corruption, Transaction Publishers, New Brunswick. London, 2009, pp. 59-76.

4. DiTella R., Schargrodsky E. The Role of Wages and Auditing During a Crackdown on Corruption in the City of Buenos Aires. Journal of Law and Economics, 2003, vol. 46, no. 1, pp. 269-292.

5. Fischer C. Corruption in Healthcare: A Problem in Germany, too. Indian Journal of Medical Ethics, 2014, vol. 11, no. 2, pp. 110-117.

6. Welsch H. Corruption, Growth, and the Environment: A Cross-Country Analysis, 2003. Discussion Paper No. 357, DIW Berlin.

7. Buckley N. Corruption and Power in Russia. Foreign Policy Research Institute, 2018.

8. Kazyrytski L. Fighting Corruption in Russia: Its Characteristics and Purpose. Social \& Legal Studies, 2020, vol. 29, no. 3, pp. 421-443.

9. Transparency International (2019) Corruption-Perception-Index 2019. Available at: https://www. transparency.de/cpi/cpi-2019/cpi-2019-tabellarische-rangliste/ (accessed: 23.09.2020).

10. Dimant E. The Antecedents and Effects of Corruption - A Reassessment of Current (Empirical) Findings, 2014. MPRA Paper No. 60947.

11. Schulze G. G., Zakharov N. Corruption in Russia - Historic Legacy and Systemic Nature. CESifo Working Paper, 2018, no. 6864, Center for Economic Studies and Ifo Institute (CESifo), Munich.

12. McKenzie R. B., Tullock G. Homo Oeconomicus. Ökonomische Dimensionen des Alltags. Frankfurt/ Main, Campus, 1984.

13. Luhmann N. Funktionen und Folgen formaler Organisation, Bd. 20. Berlin, Duncker \& Humbolt, 1964.

14. Klinkhammer J. On the Dark Side of the Code: Organizational Challenges to an Effective Anticorruption Strategy. Crime, Law and Social Change, 2013, no. 60, pp. 191-208.

15. Pohlmann M.C., Höly K., Klinkhammer J. Personal Gain or Organizational Benefits? How to Explain Active Corruption. German Law Journal, 2016, vol. 17, no. 1, pp. 73-99.

16. Fleck C., Kuzmics H. Korruption. Zur Soziologie nicht immer abweichenden Verhaltens. Athenäum, Königstein/Ts., 1985.

17. Campos J. E., Pradhan S. The Many Faces of Corruption. Tracking Vulnerabilities at the Sector Level. Washington, D.C., The World Bank, 2007.

18. Diekmann A., Voss T. Die Theorie des rationalen Handelns. Stand und Perspektiven. Diekmann A., Voss T. (eds) Rational-Choice-Theorie in den Sozialwissenschaften. Anwendungen und Probleme. Munich, Oldenbourg, 2004, pp. 13-32.

19. Becker G. S. Crime and Punishment: An Economic Approach. Journal of Political Economy, 1968, vol. 76, no. 2, pp. 169-217.

20. Festinger L. Theorie der kognitiven Dissonanz. Bern, Huber, 1978.

21. Beckmann J. Kognitive Dissonanz. Eine handlungstheoretische Perspektive. Berlin, Springer, 1984.

22. Cohen A. K. Delinquent Boys: The Culture of the Gang. New York, Free Press, 1955.

23. Merton R. K. Social Theory and Social Structure. Toward the Codification of Theory and Research. Glencoe, IL, Free Press, 1949.

24. Meier B.-D. Kriminologie ( $5^{\text {th }}$ ed.). Munich, C. H. Beck, 2006. 
25. Messner S. F., Rosenfeld R. Institutional Anomie Theory: A Macro-sociological Explanation of Crime. Krohn M., Lizotte A. and Hall G. (eds) Handbook on Crime and Deviance. New York, Springer, 2009, pp. 209-224.

26. Hermann D. Werte und Kriminalität. Konzeption einer allgemeinen Kriminalitätstheorie. Wiesbaden, Westdeutscher Verlag, 2013.

27. Levin M., Satarov G. Corruption and institutions in Russia. European Journal of Political Economy, 2000, vol. 16, pp. 113-132.

28. Avtonomov V. Balancing State, Market and Social Justice: Russian Experiences and Lessons to Learn. Journal of Business Ethics, 2006, vol. 66, pp. 3-9.

29. Cheloukhine S., King J. Corruption Networks as a Sphere of Investment Activities in Modern Russia. Communist and Post-Communist Studies, 2007, vol. 40, pp. 107-122.

30. Ledeneva A.V. Russia's Practical Norms and Informal Governance: The Origins of Endemic Corruption. Social Research, 2013, vol. 80, no. 4, pp. 1135-1162.

31. Anand V., Ashforth B.E., Mahendra J. Business as Usual: The Acceptance and Perpetuation of Corruption in Organizations. The Academy of Management Executive, 2004, vol. 18, no. 2, pp. 9-23.

32. Ashforth B.E., Anand V. The Normalization of Corruption in Organizations. Kramer R. M., Staw

B. M. (eds) Research in organizational Behavior, Bd. 25. New York, Elsevier Ltd., 2003, pp. 1-52.

33. Aguilera R. V., Vadera A. K. The Dark Side of Authority. Antecedents, Mechanisms, and Outcomes of Organizational Corruption. Journal of Business Ethics, 2008, vol. 77, pp. 431-449.

34. Campbell J.-L., Göritz A. Culture Corrupts! A Qualitative Study of Organizational Culture in Corrupt Organizations. Journal of Business Ethics, 2014, vol. 120, pp. 291-311.

35. Rabl T., Kühlmann T.M. Understanding Corruption in Organizations: Development and Empirical Assessment of an Action Model. Journal of Business Ethics, 2008, vol. 82, no. 2, pp. 477-495.

36. Staffhorst C. Wertkonflikte in Unternehmen. Eine erweiterte organisationstheoretische Analyse von Korruption. Wiesbaden, VS-Verlag, 2010.

37. Venard B., Hanafi M. Organizational Isomorphism and Corruption in Financial Institutions:

Empirical Research in Emerging Countries. Journal of Business Ethics, 2008, vol. 81, pp. 481-498.

38. Ashforth B.E., Gioia D. A., Robinson S. L., Trevino L. K. Re-viewing Organizational Corruption. The Academy of Management Review, 2008, vol. 33, no. 3, pp. 670-684.

39. Pinto J., Leana C. R., Pil F. K. Corrupt Organizations or Organizations of Corrupt Individuals? Two Types of Organization-level Corruption. Academy of Management Review, 2008, vol. 33, no. 3, pp. 685-709.

40. Pohlmann M. C., Höly K. Manipulation in der Transplantationsmedizin. Ein Fall von organisationaler Devianz?, Kölner Zeitschrift für Soziologie und Sozialpsychologie, 2017, vol. 69, pp. 181-207.

41. Berger P. L., Luckmann T. The social Construction of Reality. A Treatise in the Sociology of Knowledge.

London, Penguin Press, 1966.

42. Meyer J., Rowan B. Institutionalized Organizations: Formal Structure as Myth and Ceremony. American Journal of Sociology, 1977, vol. 83, no. 2, pp. 340-363.

43. Jepperson R.L. Institutions, Institutional Effects, and Institutionalism. DiMaggio P. J., Powell W. W. (eds) The New Institutionalism in Organizational Analysis. Chicago, IL, The University of Chicago Press, 1991, pp. 143-163.

44. DiMaggio P. J., Powell W.W. The Iron Cage Revisited: Institutional Isomorphism and Collective Rationality in Organizational Fields. American Sociological Review, 1983, vol. 48, no. 2, pp. 147-160.

45. Tacke V. Rationalität im Neo-Institutionalismus. Vom exakten Kalkül zum Mythos. Senge K., Hellmann K.-U. (eds) Einführung in den Neo-Institutionalismus. Wiesbaden, VS Verlag, 2006, pp. 89-101.

46. McAdam D., Scott W. Organizations and Movements. Davis G., McAdam D., Scott W., Zald M. (eds) Social Movements and Organization Theory. New York, Cambridge University Press, 2005, pp. 4-40.

47. Scott W. R. Institutions and Organizations. Thousand Oaks, Sage, 1995.

48. Zucker L. G. The Role of Institutionalization in Cultural Persistence. American Sociological Review, 1977, vol. 42, no. 5, pp. 726-743.

49. Venard B. Organizational Isomorphism and Corruption: An Empirical Research in Russia. Journal of Business Ethics, 2009, vol. 89, pp. 59-76.

50. Suhara M. Corruption in Russia: A Historical Perspective. Hayashi T. (ed.) Democracy and Market Economics in Central and Eastern Europe: Are New Institutions being Consolidated? Sapporo, Hokkaido University, 2004, pp. 383-403.

51. Ledeneva A. V. Russia's Economy of Favours: Blat, Networking and Informal Exchange. Cambridge, Cambridge University Press, 1998.

52. Ledeneva A.V. Unwritten Rules. How Russia Really Works. Tolkachi of the New Russian Economy. London, Centre for European Reform, 2001. 
53. Kosals L. Yu. The business climate in the clan economic system. Istoriia novoi Rossii. Ocherki, interviu. In 3 vol. Vol. 1. St. Petersburg: Norma Publ., 2011, pp. 405-448. (In Russian)

54. Berliner J.S. Factory and Manager in the USSR. Cambridge, Harvard University Press, 1957.

55. Khlevniuk O.V. Tolkachi: Parallel Boosters of the Stalinist Economic System (1930s-1950s). Cahiers du monde russe, 2018, vol. 59, no 2, pp. 233-254.

56. Liuhto K. The Transformation of the Soviet Enterprise and its Management: A Literature Review, 1999, Working Paper no. 146, ESRC Centre for Business Research, University of Cambridge.

57. Ledeneva A. V. From Russia with "Blat": Can Informal Networks Help Modernize Russia? Social Research, 2009, vol. 76, no. 1, pp. 257-288.

58. Libman A., Obydenkova A. Communism or Communists? Soviet Legacies and Corruption in Transition Economies. Economics Letters, 2013, vol. 119, pp. 101-103.

Received: July 20, 2020

Accepted: September 29, 2020

Author's information:

Alexander Fürstenberg — MA; alexander.fuerstenberg@soziologie.uni-heidelberg.de

\section{Культурные модели принятия коррумпированных решений в российских организациях}

\section{А. Фюрстенберг}

Гейдельбергский университет,

Германия, 69117, Гейдельберг, Грабенгассе, 1

Для цитирования: Fürstenberg A. Cultural patterns of corrupt decision-making in Russian organizations // Вестник Санкт-Петербургского университета. Социология. 2020. Т. 13. Вып. 4. С. 393406. https://doi.org/10.21638/spbu12.2020.403

Несмотря на формальные усилия по борьбе с коррупцией, в России она представляется постоянной, стойкой проблемой с многочисленными социальными последствиями. Причины устойчивости коррупции могут быть рассмотрены как с точки зрения инертных политическими структур, так и с точки зрения конкретных коррупциогенных механизмов на уровне акторов. Однако в первом случае отсутствует возможность обобщенного объяснения коррупции, во втором - невозможно учесть переплетение коррупционных практик с конкретными культурными моделями. Современные подходы изучения организаций позволяют плодотворно связать оба подхода в концепцию организационной коррупции. Эта концепция объясняет коррупцию как процесс нормализации в организационном контексте. Статья направлена на распространение такого подхода на аналитическую модель принятия решений в организациях. Эта модель должна: i) сохранить теоретическую обобщенность объяснения коррупционной практики, ii) оставаться концептуально открытой для анализа микро-, мезо- и макропроцессов и iii) стать достаточно конкретной для реинтеграции результатов предыдущих исследований и будущих сравнительных исследований коррупции. Исходя из неоинституциональной теоретической базы ситуации принятия решений в организациях рассматриваются в противоречии между формально-юридическими параметрами и легитимными целями организации, закрепленными в ее формальной структуре. В зависимости от того, направлены ли решения против правовых параметров и организационных целей или они принимаются в соответствии с ними, изменяется вероятность конформистских решений, информаторства (whistle blowing), индивидуальной или организационной коррупции. Теория учитывает влияние культурных феноменов 
и факторов организационной культуры на процесс принятия решений. Модель учитывает связь определенных российских концепций и понятий, предполагающих влияние на коррупцию.

Ключевые слова: организационная коррупция, неоинституциональный подход, аналитические рамки, коррумпированные решения, культурные паттерны.

Статья поступила в редакцию 20 июля 2020 г.; рекомендована в печать 29 сентября 2020 г.

Контактная информация:

Фюрстенберг Александр - магистр; alexander.fuerstenberg@soziologie.uni-heidelberg.de 